\title{
ESP Learners' Perception of ESP Program Problems at Iranian Universities (A Case Study of Islamic Azad University Najafabad Branch)
}

\author{
Omid Tabatabaei \\ Department of English, Najafabad Branch, Islamic Azad University, Najafabad, Iran \\ Azam Mokhtari \\ Department of English, Najafabad Branch, Islamic Azad University, Najafabad, Iran
}

\begin{abstract}
Admittedly, ESP courses are mainly designed to equip the students with the language skills which will allow them to function in the target situation or work domain. Realizing the need for more investigation, the present research examined problems of the ESP program in Iran focusing on ESP teachers' and learners' perception, with particular reference to Islamic Azad University Najafabad Branch. To fulfill the purposes of the study, 102 Iranian ESP learners (male and female) majoring in computer engineering, electronic engineering, and civil engineering, BSc level from Islamic Azad University of Najafabad participated in the study. The main instruments which were found appropriate for the purposes of the present research was a questionnaire consisting of some items related to ESP learners' needs, attitudes. The results of the study suggest that students' internal motivation to learn English can be the outcome of an ESP program in which learners' needs, nature of students' majors and their professional needs are the focus of attention.
\end{abstract}

Index Terms - English for Specific Purposes, perception, needs, motivation

\section{INTRODUCTION}

ESP programs have been implemented since the early 1960s. The courses are taught at universities in order to meet students' specific needs, and prepare them for academic and vocational contexts in future (Chang, 2009; Tsao, 2011). Iranian ESP learners usually enroll in the course not for the sake of language knowledge but in order to be able to function in a specific context using the language as a tool. Moreover, ESP courses address the students who start learning English as a compulsory course in the secondary school. University ESP students receive 2 hours of English instruction a week to pass a two-credit course which has some main components like translation and technical vocabularies. Evaluation tools used in order to assess the students' performance are stated to be written midterm and final exam.

Iranian ESP learners basically receive most of their language input through textbooks and the language practice which takes place in the classroom. Most of the ESP teachers consider textbooks as the foundation for the content of the lessons (Karimi, Sadeghi, Behnam Nia, Esmaeeli Salumahaleh, Mirzaei, \& Farokhzadi, 2013). ESP in Iran is a novel area and ruled by traditional ways of teaching, consequently many significant areas including ESP teachers' education have been ignored or even untouched scientifically which might be the effect of local, cultural and educational policies (Ghanbari \& Eslami Rasekh, 2012).English instructors teaching ESP do not have any special training or instruction before being required to teach those ESP courses (Sherkatolabbasi\& Mahdavi-Zafarghandi, 2012). Therefore, the present study is aimed at improving ESP learning condition in Iran through introducing some problems related to the ESP program.

Hutchinson (1987) explains that special group of learners need a particular type of English according to their requirements so by analyzing the linguistic characteristics of their special area of profession or study, their language can be identified. "Tell me what you need English for and I will tell you the English that you need" became the guiding principle of ESP (P.8). Liu (2007) defines ESP as a part of "Language for Specific Purposes" (LSP), which is more general and does not only put its attention on teaching English, but also on French as well as German.

In fact, needs analysis is one of the fundamental assumptions in syllabus design because syllabus design originates from them. Luttikhuizen (2000) also asserts that while designing materials for ESP course, some components (grammatical, functional, notional, lexical, discourse and rhetorical ones) are chosen which are relevant to the specific field so he disagrees with the idea of mere teaching of a number of technical terms (Luttikhuizen, 2000).

Due to the fact that ESP learners are supposed to learn English in a really restricted time, it is necessary to teach them the most important and useful parts they need. So the ESP course developers and designers must consider learners' needs and try to design around them (Basturkmen, 2006). In order to provide an appropriate design, any type of syllabus or methodology might be applied, but, due to the time restrictions, a task-based and communicative approach is suggested (Byram, 2004). While designing ESP course, corpora can be really helpful and effective. As a matter of fact, 
an important teaching problem is grasping essential points in ESP courses which is an inseparable part of single teaching environments (Gavioli, 2005).

Due to the fact that different methodologies follow particular purposes, today attention to the methodology plays a really significant role in curriculum design or material design (López \& Jiménez, 2010). López and Jiménez (2010) also state the considerable importance of materials and its effects on ESP teaching. They believe that materials should be authentic, up-to-date and relevant to the special needs of ESP learners. In fact, ESP materials-driven has been proposed and as a result the necessity to employ instructors who evaluate their course books carefully has been felt. Their criterion for this evaluation is how appropriate the materials are for the ESP students. There is no doubt that specificity is a significant feature of ESP research today. However, ESP field will have to consider English as an international language (Hinkel, 2005).

Students attend in ESP classes with some information about their specialist fields and also different ways of communication. Communication knowledge is considered really significant due to some reasons. Clearly, it means that ESP teachers can rely on their students when designing different activities especially communicative ones. So negotiation seems necessary in this condition. Cooperation between ESP teachers and learners can be seen when learners' specialist knowledge is employed as a learning resource. ESP teachers' role is prominent in helping learners to activate and build on their latent understandings in order to communicate their intentions (Dudley-Evans\& St John, 1998).

Numerous studies have been conducted on ESP-related issues. In some of them teaching methods used in ESP classes was the focus of attention(Yang et al., 1994), some considered different types of ESP courses or materials (Chang, 1992; Huang, 1997), some focused on the needs of the learners (Lee, 1998; Yang \& Sue, 2003), whereas others discussed the learning strategies of ESP students (Hsu, 2008; Yang, 2005). Still so many other aspects are under research.

Suzani, Yarmohammadi and Yamini (2011) found that teaching materials and textbooks should be less wordy so they will be more interesting for the ESP learners. In addition, the physical shape of the textbooks, in general, and the presentation of materials and arrangement of activities, in particular, have to be considered two important factors which directly affect the students' interest and motivation (p. 197). Moreover, four basic skills of the language need enough attention and the exercises related to their improvement should be as authentic as possible. The style of the book and teaching style should support each other and ESP teachers have to be allowed to use their creativity as well. In order to make students less confused, vocabulary presentation and terminology should be taught in a really neat and compact way. In fact encouraging the learner autonomy also plays a leading part in ESP pedagogy.

Tsao, Wei and Fang (2008) investigated the perceptual similarities and differences between students and teachers with regard to the demand for ESP in vocational universities. Their findings showed that teachers and students agreed on the following: 1) for technological students, ESP seems essential; 2) before students start ESP learning, they require acceptable grounding in basic English skills; 3) training language communication skills as well as integrating terminology and subject content in to the course should be the focus of attention in ESP instruction; 4) ESP instructors should be proficient in English teaching and also the subject content knowledge; 5) some problems affect the effectiveness of both general English curricula and ESP negatively

Petrova (2008) considered objective and subjective needs analysis and concluded that ESP is a really valuable course for the college students. According to the findings of his research, at the beginning of the ESP course, some learner training activities must be included, because there are not any homogeneous groups and learners will have to work independently during the course. Since the course is really short, the best suggestion is teaching students different ways of improvement.

Through studying previous studies on ESP, one notices that, more studies are needed to enrich the literature. As a result, an attempt has been made in this study to fill the gaps in the previous literature.

\section{Statement of The PROBlem}

It is not evident if the ESP courses offered to the students at Iranian universities have seriously considered their specific needs. It is also questionable whether or not the technical English course presently offered at the Iranian universities is up-to-date and truly catered to students' needs. In fact, the method of teaching ESP may be outdated, which could bore or even insult the learners. Indeed, the traditional way of ESP instruction in limited hours is not pertinent to the current situation of ESP students. The ESP instruction has mostly focused on presenting special words, reading and translating numerous texts so, English is not used in communicative way during most of the lessons.

Actually, Iranian universities have not used special techniques to satisfy the needs of ESP learners. Students and teachers in Iran face some significant problems in using ESP such as: boredom, inactivity and low language proficiency, overcrowded classes, uninterested and demotivated students, communication problems, lack of opportunity to use that language in their daily lives and excessive use of translation activities in classes (Barjesteh \&Shakeri, 2013).

Today, it is generally accepted that demands for wider access to education have made ESP classes more crowded than ever before and there are students with different proficiency levels which make language teaching really difficult. Although, the ESP courses are rather demanding, there does not seem to be any attempt to incorporate the use of communicative activities and most Iranian universities prefer to produce their own materials. 
The medium of instruction at schools and even universities in Iran is the national language, Farsi. However, it seems necessary for university students to be able to read English language books, articles, journals, and Internet sources related to their fields of study (Barjesteh \& Shakeri, 2013)

\section{OBJeCtives OF THE STUdy}

The present research aimed at investigating the problems of Iranian ESP students at Iranian universities. It also makes researchers, teachers, textbook developers and policy makers cognizant of the fact that ESP program needs a lot of attention. Furthermore, it sheds light on identifying the language needs of ESP students at Iranian universities to find out to what extent these needs have a proper place in the syllabus design and material preparation

\section{RESEARCH QUESTIONS}

An attempt has been made in this study to seek appropriate answers to the following questions: RQ1: In students' opinions, to what extent should English be used in ESP classes?

RQ2: What are the perceptions of ESP students regarding their needs in ESP courses?

RQ3: How do students evaluate their ESP instructors?

\section{SIGNIFICANCE OF THE STUDY}

Although there has been a lot of research focused on this topic, it is still one of the most challenging and controversial issues in our country. Therefore, the current study has investigated ESP learners' and teachers' perception of ESP program problems at Iranian universities. In fact, this issue is so urgent that it calls for effective investigation. Actually, careful examination of the expectations and perceptions of the ESP learners and instructors is seen to be important in determining the success of ESP courses. There can be a variety of solutions, with the ones suggested in this research among the most frequently implemented by ESP practice in the world. The findings of this study may be helpful for researchers, material designers, teachers and specially the ESP students.

\section{Methodology}

This section presents the information about the participants, materials, data collection, and the method of analyzing the data.

\section{A. Participants}

Participants who were involved in this study consisted of 102 Iranian students (male and female) majoring in computer engineering, electronic engineering, and civil engineering, BSc level and the rationale was that these students had been exposed to the ESP program as a university requirement, thus, they were able to give feedback on the ESP course. They were between 19 and 25 years old. All of them were Persian L1 speakers.

\section{B. Instruments}

The main instrument, which was found appropriate for the purposes of the present research, was the questionnaire. To construct and develop the questionnaires, the following procedures were followed. First, a number of research studies related to ESP course was reviewed and then examples of some questionnaires were studied in order to have a guideline. Based on the information gathered and considering the purpose of the study and the research questions, the questionnaires were constructed. Content validity was established by asking four experts to give their opinions on the first draft of the questionnaire. They were experts in research methodology, text and discourse analysis, testing and phonology. They were asked to comment on the relevance of questions to the purpose of the questionnaire, possible wording and interpretation problems in questions and instructions, and on the type and order of questions. Based on the experts' opinions, the proportion of questions was reduced. Experts also expressed their concerns as regards the overall format of the questionnaire, which was addressed as well. Then, they were piloted on 30 ESP students to ascertain their reliability and applicability so they were analyzed for reliability value by using Cronbach alpha in SPSS program. The Cronbach alpha was frequently used to estimate reliability of questionnaires with rating scales. The result revealed that alpha reliability coefficient of the questionnaires was .85 .

The ESP students were administered an anonymous questionnaire in Persian divided into four parts (see appendix A). The first section contains questions on biographical data including age, gender and major of the participants and their general opinions. The second section contained 15 questions reflecting ESP learners' needs and a 5- point Likert Scale ranged from very strong need to very little need. This section includes some items related to different skills such as vocabulary, grammar, reading comprehension and listening. Other items in this section are concerned with the qualities of ESP teachers' methodology, materials and also evaluation. The third section contained 15 questions reflecting ESP learners' attitudes and a 5-point Likert Scale ranging from very good to poor. It includes 4 items aiming at measuring the respondents' skills of vocabulary, grammar, reading comprehension and listening comprehension. Respondents evaluate ESP teachers in other 15 questions concerning instruction method, using visual materials, appropriate exercises, and assessment. 


\section{Procedure}

To accomplish the purposes of this study, the following procedures were followed. The questionnaires were distributed among participants including ESP teachers and students while they were supported with any technical or non-technical information they demanded. It is worth mentioning that, since the average English proficiency of the students did not suffice to understand and respond to the questionnaires in its original language (English), they were translated into Persian so that students could thoroughly perceive the items and reflect on them. To guarantee a positive participation, the subjects were informed that their answers would be confidential and they would not be required to write or give their names at any stage of the study. Participants filled out the questionnaires. Questionnaires were administered by the researcher and learners and teachers were given instructions indicating that the survey was anonymous and for the purposes of finding out the problems of ESP learners. Moreover, the students were told that their answers and opinions would not affect their grades. Respondents were encouraged to ask questions at any time during the process.

\section{DATA ANALYSIS}

Analyses of responses involved qualitative methods and descriptive statistics. The mean scores and standard deviations of the ratings given by the students and teachers, frequency and percentage were analyzed statistically through SPSS. The options for the five-point Likert scale were from 1 to 5 in the electronic format of the questionnaire, as the platform did not provide other possibilities. Therefore, scores had to be given different weight in order to make them as close to nominal data as possible for frequency and percentage.

\section{RESULTS}

Item 1 of the students' questionnaire sought to find out to what extent English should be used for class participation by students. Thirty-five students (34.7\%) favored a moderate use of English, 33 of them (32.7\%) said that the use of English in their ESP classes should be high, 14 (13.9\%) respondents checked small, 11 students (10.9\%) considered very high, and finally 8 students $(7.9 \%)$ wanted the use of English for class participation to be very small. The information is displayed in the following table:

TABLE 1

\begin{tabular}{ccc} 
The STUDENTS' OPINION ON EXTENT TO WHICH ENGLISH SHOULD BE USED IN ESP CLASSES \\
\cline { 2 - 3 } Very small extent & Frequency & Percentage \\
Small extent & 8 & 7.9 \\
Moderate & 14 & 13.9 \\
Great extent & 35 & 34.7 \\
Very great extent & 33 & 32.7 \\
Total & 11 & 10.9 \\
\hline
\end{tabular}

\section{A. Addressing the Second Research Question}

The next fifteen items in the questionnaire concerned the needs of the students in ESP classes. The following table summarizes the data obtained from this part of the questionnaire. 
TABLE 2

The Frequency, Percentage, Mean, and StANDARd DeViation OF the Students NeEdS IN ESP Classes $($ VERY LOW $=1$, LOW $=2$, MODERATE $=3, \mathrm{HIGH}=4$, AND VER Y HIGH $=5)$

\begin{tabular}{|c|c|c|c|c|c|c|c|c|}
\hline No. & Needs description & 1 & 2 & 3 & 4 & 5 & Mean & SD \\
\hline \multirow[t]{2}{*}{2.} & \multirow[t]{2}{*}{ Need to learn grammar } & 3 & 11 & 45 & 31 & 11 & \multirow[t]{2}{*}{3.55} & \multirow[t]{2}{*}{.92} \\
\hline & & $3 \%$ & $10.9 \%$ & $44.6 \%$ & $30.7 \%$ & $10.9 \%$ & & \\
\hline \multirow[t]{2}{*}{3.} & \multirow[t]{2}{*}{ Need to learn technical terms } & - & 2 & 15 & 32 & 52 & \multirow[t]{2}{*}{4.32} & \multirow[t]{2}{*}{.80} \\
\hline & & $0 \%$ & $2 \%$ & $14.9 \%$ & $31.7 \%$ & $51.5 \%$ & & \\
\hline \multirow[t]{2}{*}{4.} & \multirow{2}{*}{$\begin{array}{l}\text { Need to have enough information about reading and } \\
\text { comprehending specialized English texts }\end{array}$} & 1 & 9 & 35 & 37 & 19 & \multirow[t]{2}{*}{3.63} & \multirow[t]{2}{*}{.92} \\
\hline & & $1 \%$ & $8.9 \%$ & $34.7 \%$ & $36.6 \%$ & $18.8 \%$ & & \\
\hline \multirow[t]{2}{*}{5.} & \multirow{2}{*}{$\begin{array}{l}\text { Need to understand specialized conferences presented in } \\
\text { English }\end{array}$} & - & 5 & 39 & 38 & 19 & \multirow[t]{2}{*}{3.70} & \multirow[t]{2}{*}{.83} \\
\hline & & $0 \%$ & $5 \%$ & $38.6 \%$ & $37.6 \%$ & $18.8 \%$ & & \\
\hline \multirow[t]{2}{*}{6.} & \multirow{2}{*}{$\begin{array}{l}\text { Need to have instructors who teach English in an } \\
\text { understandable way }\end{array}$} & 3 & 3 & 12 & 31 & 52 & \multirow[t]{2}{*}{4.24} & \multirow[t]{2}{*}{.98} \\
\hline & & $3 \%$ & $3 \%$ & $11.9 \%$ & $30.7 \%$ & $51.5 \%$ & & \\
\hline \multirow[t]{2}{*}{7.} & \multirow{2}{*}{$\begin{array}{l}\text { Need to have access to reliable resources and books for } \\
\text { teaching ESP }\end{array}$} & 1 & 5 & 26 & 40 & 29 & \multirow[t]{2}{*}{3.90} & \multirow[t]{2}{*}{.91} \\
\hline & & $1 \%$ & $5 \%$ & $25.7 \%$ & $39.6 \%$ & $28.7 \%$ & & \\
\hline \multirow[t]{2}{*}{8.} & \multirow{2}{*}{ Need to use appropriate audiovisual aids for teaching ESP } & 3 & 14 & 21 & 31 & 32 & \multirow[t]{2}{*}{3.74} & \multirow[t]{2}{*}{1.13} \\
\hline & & $3 \%$ & $13.9 \%$ & $20.8 \%$ & $30.7 \%$ & $31.7 \%$ & & \\
\hline \multirow[t]{2}{*}{9.} & Need to have effective exercises conducive to learning & 1 & 3 & 30 & 40 & 27 & 3.88 & .87 \\
\hline & & $1 \%$ & $3 \%$ & $29.7 \%$ & $39.6 \%$ & $26.7 \%$ & & \\
\hline 10. & Need to have instructors who pronounce words accurately & - & 3 & 14 & 48 & 36 & 4.25 & .80 \\
\hline & & $0 \%$ & $3 \%$ & $13.9 \%$ & $37.6 \%$ & $45.5 \%$ & & \\
\hline 11. & Need to have instructors who teach grammar well & 1 & 8 & 37 & 30 & 25 & 3.69 & .96 \\
\hline & & $1 \%$ & $7.9 \%$ & $36.6 \%$ & $29.7 \%$ & $24.8 \%$ & & \\
\hline 12. & Need to have instructors who teach vocabulary well & 2 & 7 & 19 & 41 & 32 & 3.93 & .98 \\
\hline & & $2 \%$ & $6.9 \%$ & $18.8 \%$ & $40.6 \%$ & $31.7 \%$ & & \\
\hline 13. & Need to have instructors who adequately guide students in & - & 7 & 24 & 43 & 27 & 3.89 & .88 \\
\hline & their ESP courses & $0 \%$ & $6.9 \%$ & $23.8 \%$ & $42.6 \%$ & $26.7 \%$ & & \\
\hline 14. & Need to have instructors who review the lessons regularly & 2 & 9 & 39 & 35 & 16 & 3.53 & .93 \\
\hline & & $2 \%$ & $8.9 \%$ & $38.6 \%$ & $34.7 \%$ & $15.8 \%$ & & \\
\hline 15. & Need to have formative assessment & 1 & 12 & 42 & 32 & 14 & 3.45 & .91 \\
\hline & & $1 \%$ & $11.9 \%$ & $41.6 \%$ & $31.7 \%$ & $13.9 \%$ & & \\
\hline 16. & Need to have instructors who, besides knowing English, & 1 & 5 & 22 & 32 & 41 & 4.05 & .95 \\
\hline & know enough about the students' field of study & $1 \%$ & $5 \%$ & $21.8 \%$ & $31.7 \%$ & $40.6 \%$ & & \\
\hline
\end{tabular}

If it could be assumed that the mean score of the choices for each item is 3 (since $1+2+3+4+5 / 5=3$ ), then it could be argued that all the questionnaire items from 2 to 16 have mean scores above 3 , implying that the students have felt that all the propositions stated in these questionnaire items are needed in ESP classes. However, the students' needs have a degree. If the mean scores for the questionnaire items are arranged in a descending order, then the most urgent need would stand on the top of the list and the least important needs would follow.

\section{B. Addressing the Third Research Question}

The next eleven items in the questionnaire reflect the students' evaluations of their professors. The synopsis of the results for this part is displayed in the following table.

TABLE 3

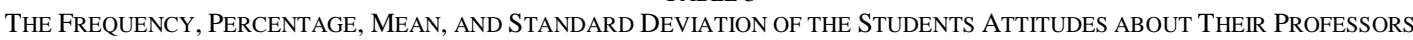
$($ VERY POOR $=1$, POOR $=2$, MODERATE $=3$, GOOD $=4$, AND VERY GOOD $=5)$

\begin{tabular}{|c|c|c|c|c|c|c|c|c|}
\hline No. & Students' attitudes and evaluations & 1 & 2 & 3 & 4 & 5 & Mean & SD \\
\hline \multirow[t]{2}{*}{17.} & \multirow[t]{2}{*}{ Instructors teach in an understandable way. } & 4 & 19 & 38 & 32 & 8 & \multirow[t]{2}{*}{3.20} & \multirow[t]{2}{*}{.97} \\
\hline & & $4 \%$ & $18.8 \%$ & $37.6 \%$ & $31.7 \%$ & $7.9 \%$ & & \\
\hline \multirow[t]{2}{*}{18.} & \multirow[t]{2}{*}{ They use reliable books and sources. } & 6 & 23 & 44 & 24 & 4 & \multirow[t]{2}{*}{2.97} & \multirow[t]{2}{*}{.93} \\
\hline & & $5.9 \%$ & $22.8 \%$ & $43.6 \%$ & $23.8 \%$ & $4 \%$ & & \\
\hline \multirow[t]{2}{*}{19.} & \multirow[t]{2}{*}{ They utilize audiovisual aids. } & 42 & 34 & 15 & 8 & 2 & \multirow[t]{2}{*}{1.95} & \multirow[t]{2}{*}{1.03} \\
\hline & & $41.6 \%$ & $33.7 \%$ & $14.9 \%$ & $7.9 \%$ & $2 \%$ & & \\
\hline \multirow[t]{2}{*}{20.} & \multirow{2}{*}{$\begin{array}{l}\text { They assign effective exercises which are conducive to } \\
\text { learning. }\end{array}$} & 21 & 37 & 31 & 12 & - & \multirow[t]{2}{*}{2.33} & \multirow[t]{2}{*}{.94} \\
\hline & & $20.8 \%$ & $36.6 \%$ & $30.7 \%$ & $11.9 \%$ & $0 \%$ & & \\
\hline \multirow[t]{2}{*}{21.} & \multirow[t]{2}{*}{ They pronounce words accurately. } & 2 & 15 & 36 & 34 & 14 & \multirow[t]{2}{*}{3.42} & \multirow[t]{2}{*}{.97} \\
\hline & & $2 \%$ & $14.9 \%$ & $35.6 \%$ & $33.7 \%$ & $13.9 \%$ & & \\
\hline \multirow[t]{2}{*}{22.} & \multirow[t]{2}{*}{ They give good explanations about the technical terms. } & 3 & 9 & 43 & 40 & 6 & \multirow[t]{2}{*}{3.36} & \multirow[t]{2}{*}{.84} \\
\hline & & $3 \%$ & $8.9 \%$ & $42.6 \%$ & $39.6 \%$ & $5.9 \%$ & & \\
\hline \multirow[t]{2}{*}{23.} & \multirow[t]{2}{*}{ They provide good grammatical explanations. } & 5 & 15 & 43 & 32 & 6 & \multirow[t]{2}{*}{3.18} & \multirow[t]{2}{*}{.93} \\
\hline & & $5 \%$ & $14.9 \%$ & $42.6 \%$ & $31.7 \%$ & $5.9 \%$ & & \\
\hline \multirow[t]{2}{*}{24.} & \multirow[t]{2}{*}{ They adequately guide the students in their ESP courses. } & 7 & 24 & 43 & 19 & 8 & \multirow[t]{2}{*}{2.97} & \multirow[t]{2}{*}{1.01} \\
\hline & & $6.9 \%$ & $23.8 \%$ & $42.6 \%$ & $18.8 \%$ & $7.9 \%$ & & \\
\hline \multirow[t]{2}{*}{25.} & They regularly review the lessons. & 11 & 30 & 32 & 24 & 4 & 2.80 & 1.04 \\
\hline & & $10.9 \%$ & $29.7 \%$ & $31.7 \%$ & $23.8 \%$ & $4 \%$ & & \\
\hline 26. & They have formative assessment of the students. & 15 & 28 & 38 & 16 & 4 & 2.66 & 1.04 \\
\hline & & $14.9 \%$ & $27.7 \%$ & $37.6 \%$ & $15.8 \%$ & $4 \%$ & & \\
\hline 27. & They know about the students' field of study. & 9 & 19 & 34 & 29 & 10 & 3.11 & 1.10 \\
\hline & & $8.9 \%$ & $18.8 \%$ & $33.7 \%$ & $28.7 \%$ & $9.9 \%$ & & \\
\hline
\end{tabular}


The top quality of the ESP professors, as judged by their students, is that they pronounce words accurately $(M=3.42)$, followed by the fact that they provide good explanations about the technical terms $(M=3.36)$, they teach in an understandable way $(M=3.20)$, they provide good grammatical explanations $(M=3.18)$, and they know about the students' field of study $(M=3.11)$. The mean score of the other questionnaire items about the evaluation of professors fall below 3. This means that the students do not hold very high opinions about these issues: instructors guide their students in the ESP courses $(M=2.97)$; they use reliable books and sources $(M=2.97)$; they regularly review the lessons $(M=2.80)$; they have formative assessment of their students $(M=2.66)$; they assign effective exercises which are conducive to learning $(M=2.33)$; and they use audiovisual aids $(M=1.95)$.

\section{DISCUSSION}

Item 1 of the students' questionnaire sought to find out to what extent English should be used for class participation by students. Most of the ESP learners favored moderate or high use of English in their ESP classes. In the same vein, Mazdayasna and Fazilatfar (2010) investigated Iranian ESP learners' and instructors' beliefs and attitudes concerning the use of native language and it was the result they stated : most of the students majoring in humanities, engineering and sciences as well as their teachers agreed with the use of L1 in particular situations as a kind of pedagogic device in order to teach different language functions : explaining the meaning of technical and semi-technical words, grammatical structures and difficult ideas or concepts, explaining the methodology and content of the text, giving instructions for tasks and exercises, teaching reading strategies, helping students feel more confident, correcting errors, checking students' comprehension of grammatical structures, checking the meaning of new words and content of the lesson and highlighting similarities and differences between L1 and L2 language forms.

In fact needs analysis is a kind of device which is helpful in establishing the how and what of a course. Needs is like an umbrella term including many aspects such as incorporating learners' goals and backgrounds, their language proficiencies, their reasons for taking the course, their teaching and learning preferences, and the situations they will need to communicate in . Different participants have different needs, so it is not easy to determine them (Hyland, 2006). That is why the next fifteen items in the questionnaire concerned the needs of the students in ESP classes. It could be argued that all the questionnaire items from 7 to 21 have mean scores above 3 , implying that the students have felt that all the propositions stated in these questionnaire items are needed in ESP classes. This means that the student felt their needs could be arranged, from the most to the least important needs, in the following order: need to learn technical terms, have instructors with accurate pronunciations, have teachers who teach in an understandable way, have instructors who know enough about the students' field of study, have instructors who teach vocabulary well, have access to reliable sources and books, have teachers who adequately guide students in their ESP courses, have effective exercises conducive to learning, use audiovisual aids, understand the specialized conferences in English, have instructors who teach grammar well, have enough information for reading and comprehending ESP texts, have teachers who regularly review the lessons, have formative assessment, and finally need to learn grammar. Zhang (2013) states that one of the important characteristics of ESP teachers is having enough information in these two fields: advanced level of English and professional knowledge and experience. ESP teachers are demanded who are proficient in professional training, the employment organizations and guidance. Teachers with these features can prepare students for the skills in related fields. They can guide ESP learners to practice related activities as well.

The next eleven items in the questionnaire reflect the students' evaluations of their professors. The mean score of some of the questionnaire items about the evaluation of professors fall below 3 . This means that the students do not hold very high opinions about these issues: instructors guide their students in the ESP courses $(M=2.97)$; they use reliable books and sources $(M=2.97)$; they regularly review the lessons $(M=2.80)$; they have formative assessment of their students $(M=2.66)$; they assign effective exercises which are conducive to learning $(M=2.33)$; and they use audiovisual aids $(M=1.95)$.

Alibakhshi, Ghand Ali and Padiz (2011) put their effort into reviewing teaching and testing in ESP program planning. The results of their study showed that a successful ESP teacher must possess general qualifications of a good teacher as well as enough information related to principles of adult learning. A successful ESP teacher should make an attempt to develop all various components of ESP program, should try hard to get information about the discourse and content of the subject matter which s/he is supposed to teach in order to have meaningful communication. Involving a total innovation in academic test while considering both functions and forms is really necessary. Portfolio assessment can be a good approach to testing in ESP program instead of traditional ones.

\section{CONClusion}

Currently, English is considered an indispensable part to the higher education in Iran. The historical overview suggests that the role and status of English in Iran have reached unprecedented heights, although fundamental problems remain. The present study has investigated some of these problems in universities. Concerning the goals of study and the research questions, the following results were obtained. 
1. It seems necessary for university students to be able to read English language books, articles, journals, and Internet sources related to their fields of study so it seems necessary to consider English as the significant medium of instruction at schools and even universities.

2. ESP instructors have a vital role in conducting ESP classes.

3. In ESP classes using reliable books and sources have not received enough attention and ESP learners favored effective exercises which are conducive to learning.

4. ESP learners and teachers favored using audiovisual aids in their classes.

5. Reviewing the lessons, formative assessments of the students seem really helpful in ESP classes.

6. Increasing the time of ESP classes leads to better syllabus design.

\section{Pedagogical Implications}

This study offers a number of implications for classroom teaching, ESP teachers, researchers and material designers. First, most of the students favored a moderate or even high use of English in their ESP classes. Clearly, it means that ESP teachers can rely on their students when designing different activities especially communicative ones. In order to provide an appropriate design, any type of syllabus or methodology might be applied, but, due to the time restrictions, a task-based and communicative approach is suggested (Byram, 2004). Owing to the fact that most of the ESP learners are considered as pre-intermediate or intermediate, a task-based and communicative approach is applicable.

Needs analysis is the foundation of ESP resulting in a very focused ESP course (Liu, 2007). ESP learners also appeared to significantly grasp the overall characteristics of their teachers. They need instructors who teach in an understandable way, know enough about the students' field of study, teach vocabulary well, have access to reliable sources and books, adequately guide students in their ESP courses, organize effective exercises conducive to learning, teach grammar well and regularly review the lessons.

The results of this study revealed that visual aids are not used adequately in ESP classes. In the past, pictures and images were used but nowadays they do not seem to be suitable in order to make ESP learners motivated. In order to make students interested and active, using computers and advertising can be highly effective (Fernández, 2001). 
ApPendix A. Students' Questionnaire

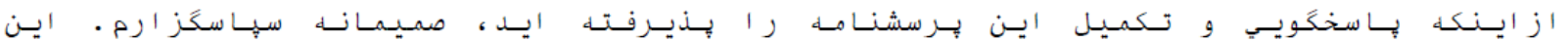

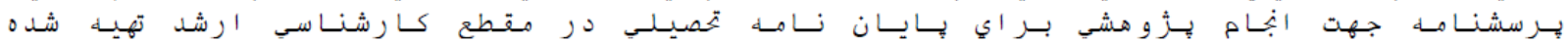

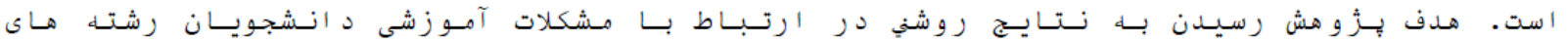

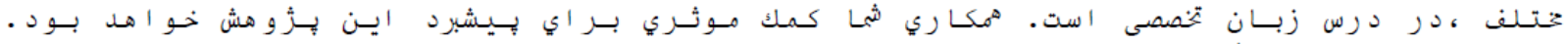

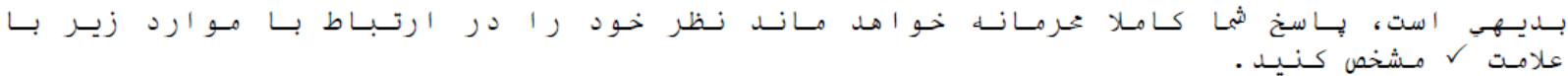

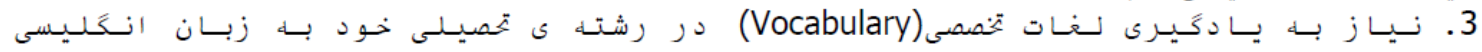
نسيـاز بـسيـار زيـاد

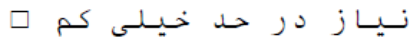

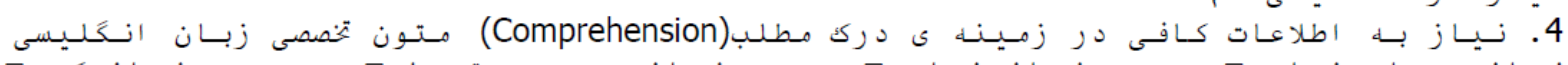

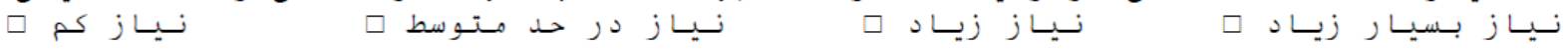

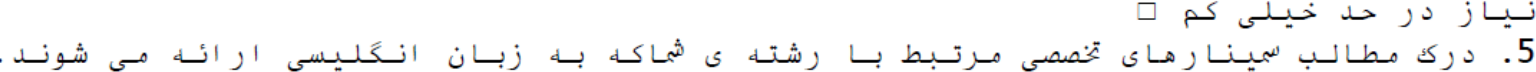

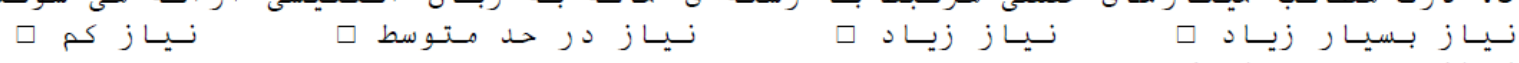

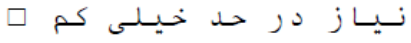

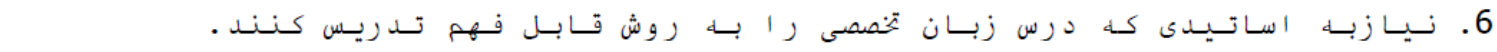
نسيـاز بسـيـار زيـاند

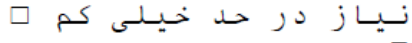

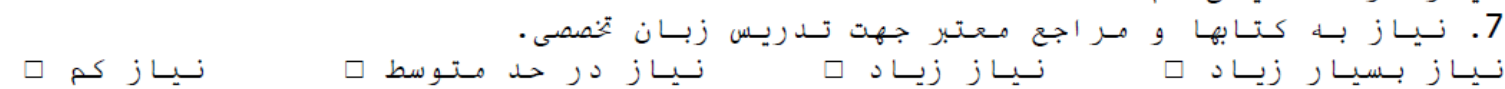

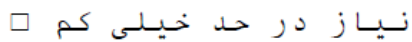

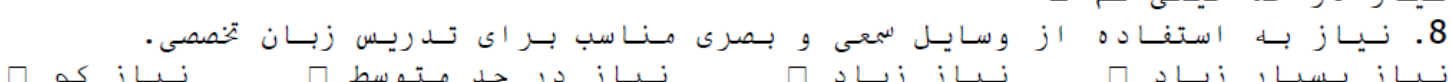

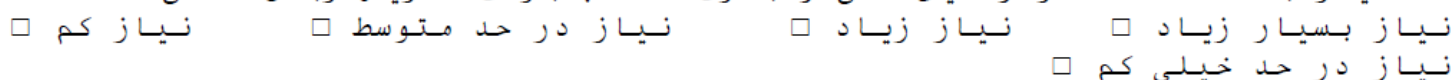

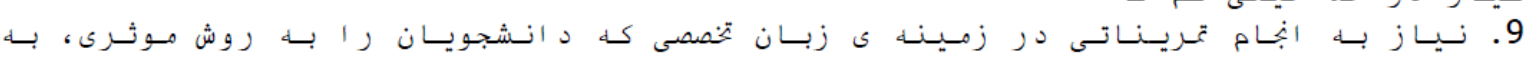

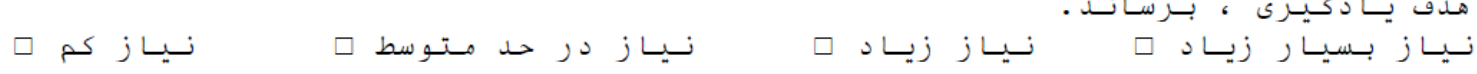

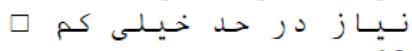

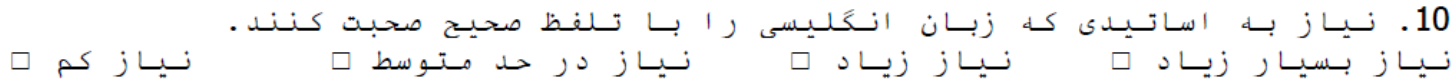

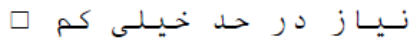




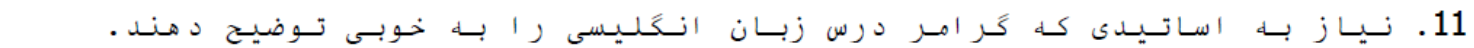

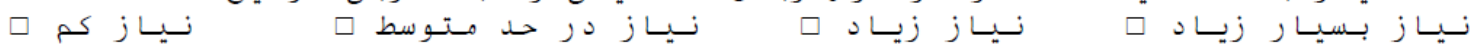

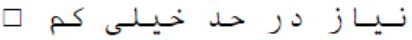

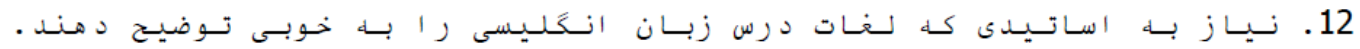

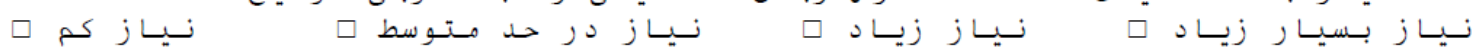

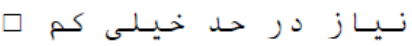

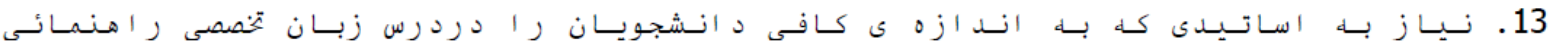

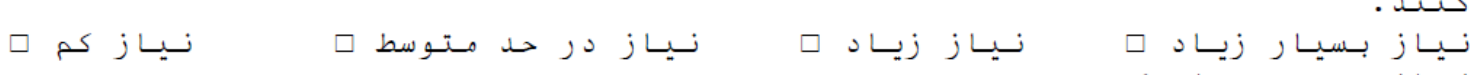

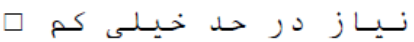

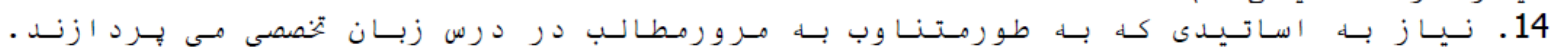

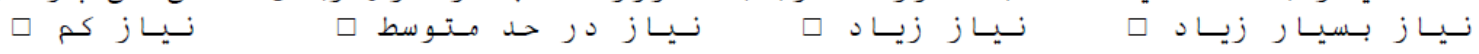

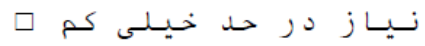

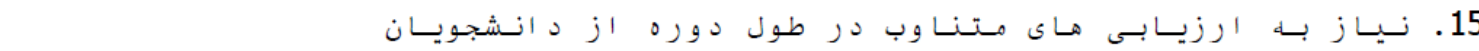

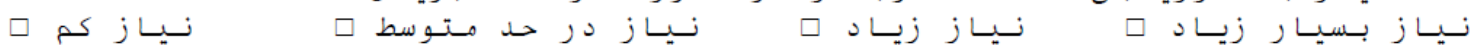

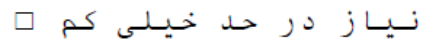

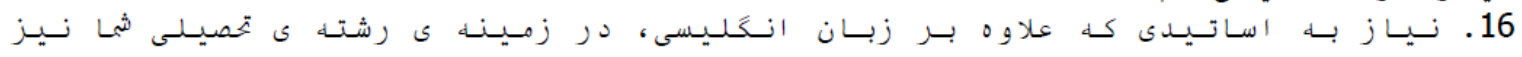

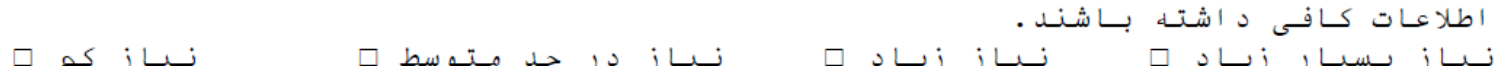

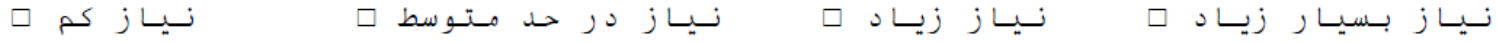

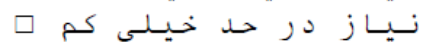

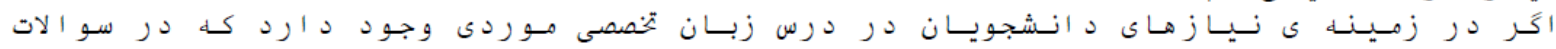

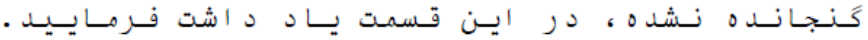

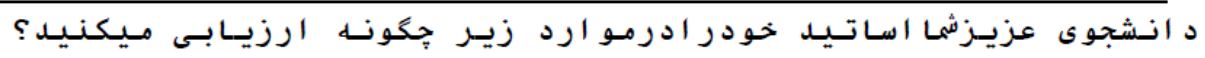

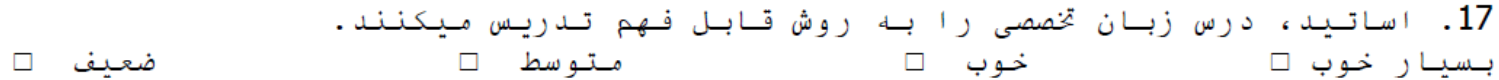

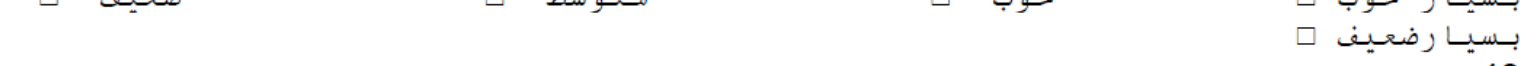

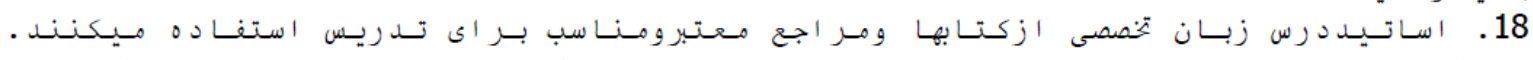

بس بسيـار خـوب

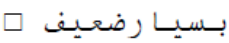

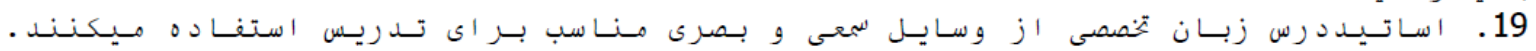

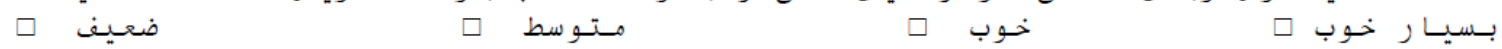

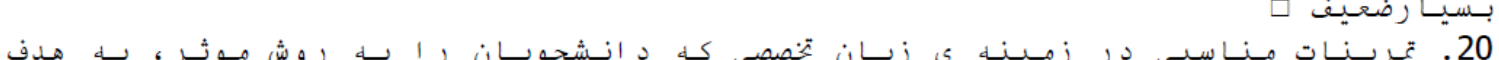

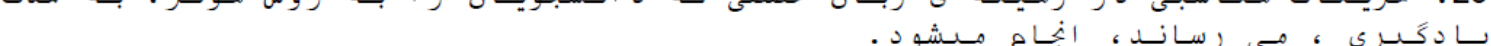

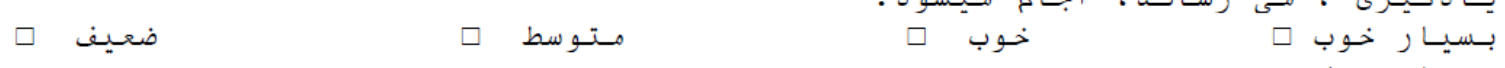

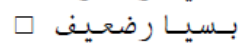

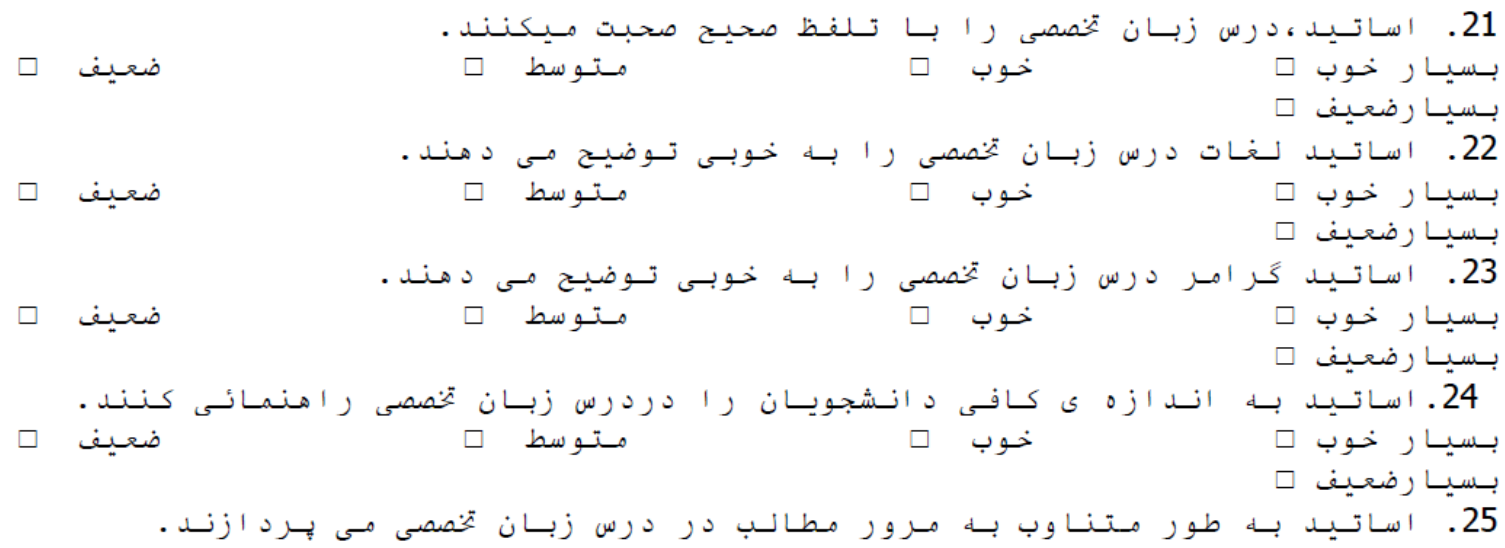




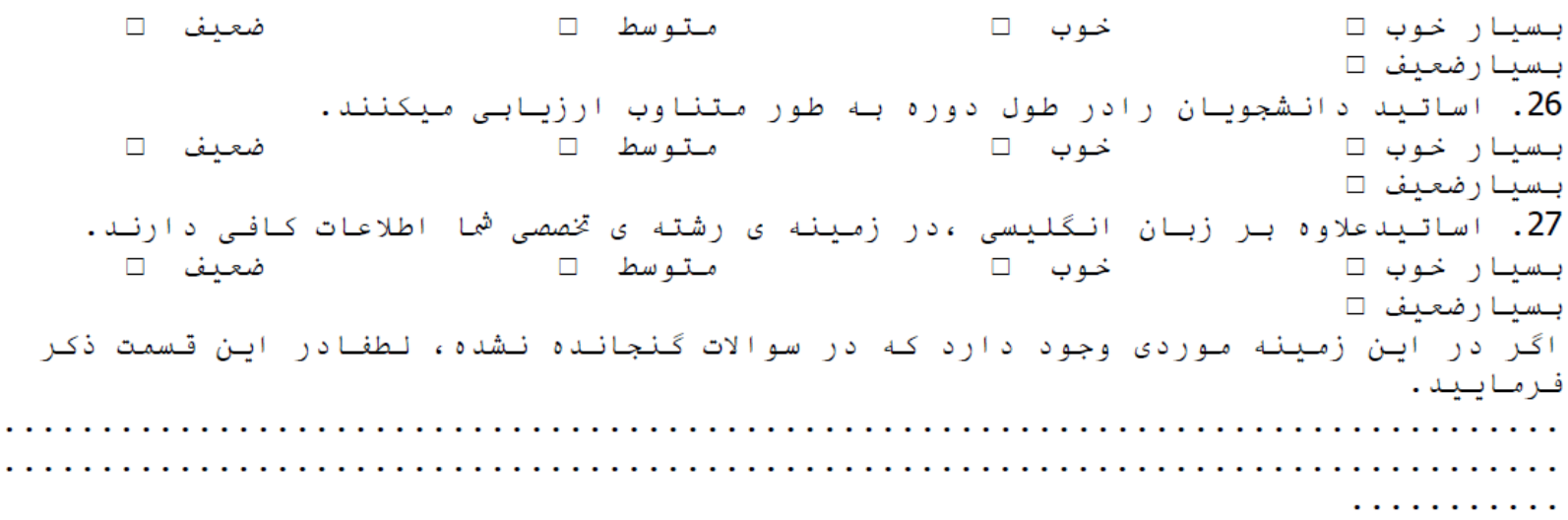

\section{REFERENCES}

[1] Alibakhshi, G., Ghand Ali, H., \& Padiz, D. (2011). Teaching and Testing ESP at Iranian Universities: A Critical View. Journal of Language Teaching and Research, 2, 1346-1352.

[2] Barjesteh, H., \& Shakeri, F. (2013). Considering The Issues of Language for Specific Purposes at Iranian Universities: Its Genesis/Problems and Suggestions. Indian Journal of Fundamental and Applied Life Sciences, 3, 540-552. http://www.cibtech.org/ (accessed 22/1/2014).

[3] Basturkmen, H. (2006). Ideas and Options in English for Specific Purposes. Routledge. http://books.google.com/ (accessed 20/1/2014).

[4] Byram, M. (2004). Routledge Encyclopedia of Language Teaching and Learning. Routledge. http://books.google.com/ (accessed 15/1/2014).

[5] Chang, B. Y. (1992). In Proceedings of the Eighth Conference on English Teaching .

[6] Chang, W.-Y. (2009). A Needs Analysis of Applying an ESP Program for Hotel Employees. Yu Da Academic Journal, 21, 116. http://ir.ydu.edu.tw/ (accessed 15/1/2014).

[7] Dudley-Evans, T., \& St John, M. J. (1998). Developments in English for Specific Purposes: A Multi-Disciplinary Approach. Cambridge University Press . http://books.google.com/ (accessed 1/1/2014).

[8] Gavioli, L. (2005). Exploring Corpora for ESP Learning (Vol. 21). John Benjamins Publishing. Amesterdam. The Netherlands.

[9] Ghanbari, B., \& Eslami Rasekh, A. (2012, February 1). ESP Practitioner Professionalization through Apprenticeship of Practice: the Case of Two Iranian ESP Practitioners. English Language Teaching, 5, 112-122. http://www.ccsenet.org/ (accessed 27/12/2013).

[10] Hinkel, E. (2005). Handbook of Research in Second Language Teaching and Learning (Vol. 1). Routledge. http://books.google.com/ (accessed 27/12/2013).

[11] Hutchinson, T. (1987). English for Specific Purposes. Cambridge University Press. http://books.google.com/ (accessed 29/11/2013).

[12] Hyland, K. (2006). Genre and Second Language Writing. University of Michigan Press. http://books.google.com/ (accessed 22/10/2013).

[13] Karimi, L., Sadeghi, B., Behnam Nia, F., Esmaeeli Salumahaleh, A., Mirzaei, K., \& Farokhzadi, A. (2013). Agricultural Extension and Rural Development ESP Textbook. Sciedu Press, 2. www.sciedu.ca/elr (accessed 20/1/2014).

[14] Liu, C.-y. (2007). A Descriptive Study of how English is Used and Learned Linguistically and Culturally in a Taiwanese Buddhist Monastery in Los Angeles. ProQuest. http://books.google.com/ Extension and Rural Development ESP Textbook. Sciedu Press, 2. www.sciedu.ca/elr (accessed 5/8/2013).

[15] López, Á. L., \& Jiménez, R. C. (2010). English in the European Context: The EHEA Challenge. Peter Lang. http://books.google.com/ (accessed 15/10/2013).

[16] Luttikhuizen, F. (2000). Ease Seminar: III Congrés Internacional sobre Llengües per a Finalitats Específiques: Actes. Edicion s Universitat Barcelona. http://books.google.com/ (accessed 15/11/2013).

[17] Mazdayasna, G., \& Fazilatfar, A. M. (2010). The Role of Native Language in Teaching English for Specific Purposes. IRANIAN JOURNAL OF APPLIED LINGUISTICS (IJAL). http://www.SID.ir/ (accessed 17/10/2013).

[18] Petrova, I. (2008). Needs Analysis as a Starting Point for Designing a Syllabus for English for Specific Purposes Courses. MA Thesis, University of Tarku, Department of English language and litrature.

[19] Sherkatolabbasi, M., \& Mahdavi-Zafarghandi, A. ( 2012, July 01). Evaluation of ESP Teachers in Different Contexts of Iranian Universities. International Journal of Applied Linguistics \& English Literature, 1, 198-205.

[20] Suzani, S. M., Yarmohammadi, L., \& Yamini, M. (2011). A Critical Review of the Current Situation of Teaching ESP in the Iranian Higher Education Institutions. Iranian EFL Journal, 6, 179 - 204.

[21] Tsao, C.-H. (2008). English-Learning Motivation and Needs Analysis: A Case Study of Technological University Students in Taiwan. Basic Research Conference of Chinese Military Academy on its 84th school anniversary. Fongshang, Taiwan. http://ir.fy.edu.tw/ (accessed 26/1/2014).

[22] Tsao, C.-h. (April 2011). English for Specific Purposes in the EFL Context: A Survey of Student and Faculty Perceptions. (W. Cheng, \& P. Robertson, Eds.) Asian ESP Journal, 7(2). http://asian-esp-jouenal.com/ (accessed 5/8/2013).

[23] Yang, C. H. (1994). A study on the use of field-specific authentic English texts in a junior college. Third International Symposium on English Teaching (pp. 171-189). Taipei: Crane Publishing.

[24] Zhong, Z. (2013). Proceedings of the International Conference on Information Engineering and Applications (IEA) 2012. Springer. http://books.google.com/ (accessed 12/12/2013). 
Omid Tabatabaei is an assistant professor of TEFL at Islamic Azad University, Najafabad Branch. He is currently the Vice-Dean of Humanities Faculty and the Head of English Department. His areas of interest are: L2 acquisition, Psycholinguistics, and Testing.

Azam Mokhtari holds an M.A in Teaching English as a Foreign Language (TEFL) at Islamic Azad University, Najafabad Branch. She has been an English teacher for about 10 years. 